\title{
Detecting Modern Slavery on Cannabis Farms: The Challenges of Evidence
}

\section{Adam Ramiz, et al. [full author details at the end of the article]}

Published online: 28 August 2020

(C) The Author(s) 2020

\section{Abstract}

Research Question To what extent could police identify victims of modern slavery among growers arrested on cannabis farms as suspects under drug laws, and what challenges of evidence would have to be met to separate offending from victimisation? Data A purposive sample of criminal history data of all Vietnamese nationals arrested for cannabis cultivation offences in Surrey/Sussex in the 3 years to $2017(N=19)$ was identified and collected. Three 'cannabis farm' cases from the period 2014-2017 were analysed to produce key information about growers, including their nationality, criminal history and possible status as modern slavery victims. The case records and interviews provide key information about the extent to which growers on farms were treated as slaves under the 2015 Modern Slavery Act.

Methods Semi-structured interviews were conducted with the three arrested growers to explore their lived experiences of recruitment and labour on the farms. Arresting police officers were also interviewed to explore how they frame the problem of cannabis cultivation and make decisions about their role in confronting it. Interview transcripts were prepared for analytic purposes. All interviewees were informed that the research was focused on the management of the policing of cannabis farms alone and full anonymity was assured.

Findings Five of the 19 Vietnamese nationals had previous criminal disposals. Of the remaining 14 individuals, five had no record and nine had various charges, but the prosecutions had not reached court.

Of the three cases examined in depth, the arrested growers provided stories consistent with their having been trafficked and subjected to 'debt bondage'. They described precarious journeys before being forced to work on UK farms. All three had been exposed to threats of violence or death for themselves and/or their families, should they attempt escape. Varying levels of mental and physical hardship were evidenced. There were a priori reasons to conclude that they were eligible to be considered modern slavery victims. When arrested, however, none had pleaded victimisation. Police officers demonstrated an ignorance of related legislation and varying levels of awareness of the possibility of modern slavery. They responded to the first impression made by the grower as a person culpable under drugs laws. Even where officers had concerns about modern slavery, no appropriate crime was recorded, and no formalised investigation followed. 
Conclusions Given reluctance or inability to frame the police response to cannabis farms under modern anti-slavery legislation, policing agencies should consider adopting more detailed practice guidelines to officers on how to react to the complex challenges involved, including the investigative opportunities that may help unearth modern slavery on cannabis farms through greater encouragement of victim accounts.

Keywords Modern slavery · Cannabis farms $\cdot$ Human trafficking $\cdot$ Slavery investigations · Failure to plead victimisation $\cdot$ Drug arrests

\section{Introduction}

Two hundred years after William Wilberforce and the UK led the world in abolishing the transatlantic slave trade, modern slavery has recently been described as 'disturbingly common' worldwide (The Economist 2017). The International Labour Organization (ILO 2017) reported that in 2016, perhaps 25 million people remained in forced labour. In 2019 the Independent Anti-Slavery Commissioner (IASC) estimated there were 136,000 victims of modern slavery and human trafficking in the UK itself. The National Crime Agency (NCA 2017) has expressed alarm at the growth in numbers: the 4577 offences of modern slavery recorded by UK police in 2018 were up $45 \%$ on the number for 2017 (IASC 2019).

The establishment in 2014 of the IASC and the introduction in 2015 of the Modern Slavery Act represented a renewed effort in recent years to combat modern slavery. Nevertheless, Her Majesty's Inspectorate of Constabulary and Fire \& Rescue Services (HMICFRS 2017) found that police forces were failing to tackle modern slavery and human trafficking, with victims often not being recognised as such, and investigations closing prematurely. Victims were then left exposed, with perpetrators able to continue exploiting the vulnerable.

This view was endorsed by the IASC Strategic Plan 2019-2021 (2019: pp. 14-15):

The new legislation established a statutory defence to protect victims who have committed criminal offences as a direct result of their exploitation. There are cases where victims have not used this defence and been imprisoned. There are cases where criminals have attempted to abuse this defence. There is little clarity about the use of this defence which makes it harder to know that victims are being protected and the system is being protected for those who seek to abuse the defence.

The charity, Hestia, which describes itself as supporting adults and children in times of crisis (https://www.hestia.org/pages/category/our-organisation), has made a police 'super complaint' about poor police practice for identifying victims of modern slavery (Hestia 2019) which is currently being investigated by the College of Policing supported by HMICFRS. It is especially concerned about the capacity of non-specialist officers to provide support and advice to possible victims. This is compounded by the ongoing concerns expressed by various NGOs about the availability and quality of legal advice. 
Much of the public interest in modern slavery, and the intersection of victimisation and offending for those caught up in a web of criminality, has focused on women trafficked for prostitution and children involved in 'county lines' offending. There are, however, substantial numbers of men, many of them foreign nationals, involved in criminal activities for which their particular circumstances make them vulnerable. Cannabis 'farms' are such an activity, referring to what are usually urban residences turned into small factories for the production of commercial quantities of drugs.

Cannabis is the UK's and the world's most popular drug by some distance and is consumed by a wide cross section of society (Winstock et al. 2017). In the UK, cannabis demand is high, with $6.5 \%$ of those aged 16 to 59 (approximately 2.1 million people) having used it in the preceding year (Home Office 2016). Importantly, cannabis has shifted from being an imported drug to being grown mainly in the UK (Potter 2010).

Research on the commercial illegal cultivation of cannabis is thin. We do not know how much of the labour force involved is enslaved. Yet recent findings suggest (Burland 2015) that cannabis growers who are victims of trafficking are actually often dealt with as offenders and that the Modern Slavery Act remains misunderstood and under-enforced (Craig 2015).

Apprehended cannabis growers may indeed be committing crimes, but the Law Society (2015) has argued that when these individuals, possibly victims of human trafficking, have been forced to work in illegal activity, a dilemma faces the criminal justice system as to how such individuals should be treated-as victims or criminals. The Law Society report described sophisticated growing operations, re-routed electricity and a highly profitable drug yield, with police and CPS seeming content to prosecute the grower. This person is often a minor who speaks no English, has no ID documents, is malnourished and is locked in the premises and forced to tend cannabis. The report suggests that the system fails to take into consideration that cultivation is a serious organised crime and trafficking operation, where the individual being prosecuted may, in fact, be a victim instead or as well.

Burland (2015) argued that the successful identification of people trafficked for cannabis cultivation is undermined by a narrow stereotype of the 'ideal' and 'innocent' human trafficking victim. The coercion, abuse and exploitation people suffered are overlooked, and the focus instead is on their consent and ambition to travel to the UK.

Hedge and Tarzi (1996) described how problems for a foreigner are exacerbated by cultural difference and their lack of awareness of the system in which they find themselves. Foreigners face different problems depending on their religion, culture, gender and country of origin. Whereas European prisoners are more likely to understand UK legal procedures in view of the similarity of the system with their own, other foreigners are more likely to be unaware of the services they are entitled to and their general rights. Many foreigners experienced poor legal representation and a lack of information about the criminal justice process and its consequences for them. Those who traffic or exploit them may well deliberately misrepresent the position they occupy. Language difficulties were a particular problem.

The National Police Chiefs Council (NPCC) (2014) described migrants who often arrive with no intention of cultivating cannabis, yet once in the UK, it became an easy way for them to pay back large debts to those who threatened their families back home. Organised crime groups regarded growers as low risk because of their anonymity; 
when discovered, they were often dealt with as residents without legal permission or prosecuted rather than being treated as trafficking victims. The NPCC concluded that there was an 'intractable' link between cannabis farms in the UK and modern slavery and that Vietnamese nationals in particular have been forced to work in cultivation. This study therefore focuses on the peculiarly ambiguous situation of this population of offender/victims.

In summary, there is a dearth of understanding about the cannabis growers' lived experiences as well as the perceptions and decision-making processes of the police officers themselves dealing with these incidents. In an age of the so-called 'empowerment' of the police, officers are meant to be given the authority to deal ethically with incidents they face. This study offers an illustrative analysis of modern slavery associated with a small number of indicative examples of cannabis farms in the UK. It is intended to enhance the understanding of modern slavery associated with commercial illegal cannabis cultivation and to explore how these cases are interpreted by the police.

Research Questions

This study aims to answer two central research questions:

1. To what extent do the police treat growers arrested on cannabis farms primarily as suspects under drug laws rather than as victims of enslavement?

2. Is there evidence that current enforcement practices for cannabis production laws have failed to detect slavery victims?

\section{Data and Methods}

The study used three methods of data collection and analysis.

First, the study obtained a police data set consisting of all Vietnamese nationals arrested and prosecuted for cannabis cultivation over a 3-year period (2014-2017) in Surrey and Sussex $(N=19)$. Their history of criminality was obtained from the Police National Computer, comprising information about previous convictions, cautions and reprimands. It also included pending prosecutions, not guilty findings at court, and nonconvictions, i.e. when an individual had been arrested for an offence but no further action had been taken.

Second, the study reviewed the written records of the formal police response to three selected cases.

Third, the study conducted semi-structured interviews with three arrested cannabis growers and the police officers involved in their arrests.

Case studies have been described by Yin (2009) as a strategy for research using multiple evidence sources which can involve the focused, empirical investigation of a particular phenomenon within its real-world context, particularly where the boundary between the phenomenon and its context is not clear. The phenomenon under investigation here is modern slavery within the context of cannabis farms. Case studies are therefore a highly valuable and appropriate strategy for this study, for which a quantitative analysis alone would be insufficient (Miles et al 2014).

These methods have clear limitations. Case studies have been criticised for their perceived lack of scientific rigour (Campbell and Stanley 1963) and may lack contextual description (Hyett et al. 2014). There may also be a lack of description of the role 
of the researcher in the case and how that influenced the development of the case study. On the other hand, they can raise important questions which might not have otherwise emerged.

The small number of interviews for the case study means this study makes no claim that those individuals interviewed can be representative of all cases of cannabis growers or police officers, yet the small number meant the individuals could be interviewed in depth.

The experiences of growers were essential for this study, so the decision about which cases to use as studies was informed by which cannabis growers could be interviewed. Organisations such as the Salvation Army and Vietnamese Embassy, which provide safeguarding for trafficked cannabis growers, were contacted, but they were protective of the people they were safeguarding, and no interviews could be arranged. So the growers were ultimately identified through personal contacts, with the crime reports providing the most recent record of where they were.

\section{Interviews of and About Three Arrested Cannabis Growers}

Case study A concerned a 34-year-old Vietnamese man in prison in the South East of England. He had been arrested for cannabis cultivation and interviewed in the presence of a legal advisor and an interpreter. Having admitted the offence, he pleaded guilty at court and was awaiting sentence. He was interviewed on two occasions through an interpreter. Contact was also made with the two police officers involved in the investigation, i.e. the interviewing officer and the officer leading the investigation, and each was interviewed.

Case study B was contacted via case study A and was in the same prison. He was a 23-year-old Vietnamese man who had received legal advice: he provided a 'no comment' interview to the police, had pleaded guilty at court and was awaiting sentence. He was interviewed through an interpreter. A telephone interview was conducted with the interviewing/investigating officer in the case.

Case study C was a 22-year-old Albanian man, in custody at a London police station, having been arrested for cannabis cultivation. The interview with him by the first author, a police officer, was conducted in the custody suite outside the legal constraints of the statutory PACE process, based on an undertaking given that the interview content would not be shared with the police investigating the case. A telephone interview was conducted later with the interviewing/investigating officer in the case.

It was not possible to pick and choose whom to interview, and given the small number of interviewees, the sample was almost certainly biased though in ways that could not be determined. The three arrestees interviewed were located opportunistically, rather than on any basis relating to the likelihood that they had been trafficked or victimised. Semi-structured interview schedules were used for both the cannabis growers and the police officers involved in their cases. The officers were told that the research was about cannabis factories, but modern slavery was not mentioned. The aim of that presentation was to avoid 'priming' them in a way that might have prompted them to give what they considered desirable answers.

The decision to use interpreters was made because the growers spoke limited English. They could convey some meaning, but the effort required to communicate 
adequately in a second language, especially when emotions or sensitive topics are broached, has been found to result in impoverished accounts (Nicassio et al. 1986; Westermeyer 1990) as well as making the accuracy and value of the data uncertain (Marshall and While 1994).

\section{Ethics}

This study posed particular ethical issues and therefore utilised the British Society of Criminology Statement of Ethics (BSC 2015). The ethics committee of the Surrey and Sussex Police 'Knowledge Exchange' group, who review all research proposals from an ethical perspective, sanctioned this work, and authorised crime data access for academic purposes, to better understand this relatively unexplored crime type and to improve the policing response to it. All crime data were anonymised and kept secure.

The qualitative aspect of this research required deeper ethical consideration, however. The cannabis growers were foreign nationals, non-English speakers, and incarcerated for offences associated with serious organised crime. Sykes (1971) described the insecurity of prison for individuals; it is an enclosed environment with a dense population of offenders. Growers may have been put at risk if it became known that they had spoken to a police officer so discretion was maintained throughout. The purpose of the research was fully explained and confidentiality and anonymity were assured.

\section{Findings}

\section{Nineteen Vietnamese Arrestees}

The analysis of the criminal histories of the 19 Vietnamese nationals arrested in connection with cannabis farming in Surrey/Sussex in the three years to 2017 showed that the majority (14) had no previous criminal disposal recorded against them in the UK, i.e. no criminal reprimand, caution or conviction. Of the 14 , however, only five had no recorded evidence of suspected criminality (as distinct from a sanction) whatever. Nine had various 'non-convictions'; that is, they had previously been charged with criminal offences yet those prosecutions had not reached court. The offences that these individuals were charged with relate to immigration and also possible involvement with cannabis. Of the five individuals with formal disposals, the offences were various: immigration matters, possible involvement in cannabis cultivation and in one case a serious assault and robbery. These findings set the context for the two Vietnamese arrestees interviewed, as well as for the one Albanian arrestee.

\section{Case Study A: The Formal Police Response}

Case study A involved an incident reported to Surrey Police in April 2015 and recorded as an offence under the Misuse of Drugs Act 1973-being concerned in the production of a class B drug. The crime report reveals that police were initially called after fire broke out in a maisonette above a laundrette on the high street of a market town. The fire was deemed non-suspicious, and nobody was present, but investigators found 349 
cannabis plants throughout the premises. The suspected cannabis grower was arrested in Nottingham 2 years later when he was stopped for a minor traffic infringement. He was taken to Surrey and interviewed under caution in relation to the 2015 offence. The interview was conducted in the presence of an interpreter and a legal advisor.

The police interview in this case lasted $23 \mathrm{~min}$. The interviewing officer asked 30 questions, of which 24 concerned the cannabis growing offence, whilst the remainder were about whether the grower was forced. The grower said he wished to plead guilty and was charged with the production of a class B controlled substance. He was remanded to court and was awaiting sentence at the time the interview for this study was done.

\section{Case Study A: The Grower's Interview}

The grower had worked as a taxi driver before he became involved in events that meant he had to leave Vietnam. He described participating in an anti-China protest in response to the Chinese deployment of an oil rig in a disputed region of the South China Sea. The police attended his house, and spoke to his wife, accusing him of inciting people to protest and therefore betraying his country. This made him fearful for his life, as a friend who had been arrested by the government was never seen again. Friends introduced him to an 'agent', who could help him leave Vietnam for the equivalent of $£ 20,000$. The grower's friends and wife accumulated some of the money. As he was unable to pay the full amount, the grower entered into a contract with the agent, which amounted to debt bondage:

I could only afford to pay them six thousand pounds, so the rest ... they told me, I have a contract with them; I have to work for them for one year to repay the debt.

This contract was accompanied by serious threats:

If I try to run away if they found me they would kill me, they said I wouldn't see my family if I tried to escape. I think they tried to threaten me in order to not escape.

The grower said it was his choice to leave Vietnam for Thailand, for his personal safety. He left with his own passport, though he did not have to use it. As he was wanted by the government, he felt unable to fly, because of airport checks, and arranged to be transported in the back of a lorry through Laos and Thailand. He felt Thailand was too close to Vietnam for his safety so then he accepted work in a European country of his choice-he selected the UK — and was told he would work as a labourer, chef, kitchen worker or cleaner.

He continued by lorry to China, where an agent took his passport, without explanation. He boarded a plane to Russia and then went by lorry once more, though sometimes he was taken on foot. He described the precariousness of the journey and the violence that the agents sometimes inflicted on the travellers:

When we were walking in the [forest] at night...from Russia to Poland...the agent doesn't want the immigration control to find out...s you have to walk for 
maybe two, three days...I saw one person had been beaten up...he walked behind me...when I turned round, he was unconscious, and people around me told me he had been beaten up...I believe he walked too slow and he making a lot of noises.

He believed this person had been killed and described several further incidents of violence. After a few weeks spent in France, he came to the UK in the back of a lorry. He was picked up and taken to a house where he stayed for a few weeks. He was then taken to the cannabis house, and it was only when he arrived that he was told about his role there. The plants were already in situ, and the agents told him how to tend them. They said they would save up money for him, help him with his immigration status and bring his family to the UK, all of which he believed.

The grower was sometimes given up to one hundred pounds and allowed to go out and buy food. He slept on a blanket on the floor, in a cannabis-free room. He was given a phone to contact his family in Vietnam, as well as five to ten pounds a week, which he spent on 'phone calls home'. He said he was never assaulted in the house. When asked whether he was able to leave the cannabis house, the grower described his trepidation, saying he felt forced to conduct the work, due to the threats he had been subjected to:

I do not dare to leave the house without telling them, because I fear for my life. Also I fear for my family's life in Vietnam. If I escape they could try to look for me and also my family. They threaten me before. They told me if I tried to escape they would harm my family, so I knew they would do it.

He remembered having been asked some questions by the police about whether he had been forced to work, or threatened, and he told them he had been. The grower's legal advisor however had asked no such questions. He said that he did not consider himself to be a trafficking victim, as it was his decision to go to the UK to work, and therefore, he could not claim that he was forced.

\section{Case Study A: The Police Interview}

The police interviewer of the grower was a 33-year-old probationary police officer. This was his first cannabis farm case. He was given a 'handover' package, including an interview plan; he was directed to interview the suspect and then refer the matter to the CPS. He did not retain any other oversight of the investigation. The officer viewed the matter relatively simply and believed he did not need much guidance:

You always go in with an open mind, but he's the suspect, he's linked to the crime as a suspect, there's no denying that, so you're interviewing him as a suspect to get a confession, or to get the points across to get the conviction or charge... I knew what to do. I didn't necessarily need any direction.

The officer said that whilst questions around trafficking had not been included in the interview plan, it was the grower's responses which made the officer ask questions about potential trafficking. He added that the interview had not lasted long, as there was 
not much to explore: the grower had admitted the offence. There was nothing to challenge him with, and he had not gone into great depth with the trafficking questions, as he was not investigating a trafficking offence. He acknowledged his ignorance of modern slavery legislation.

A further interview was done with the officer in charge (OIC) of the investigation. This interview provided a summary of his investigation, including the forensic submissions made, which led to the identification of the grower. He said that he had dealt with cannabis farm cases on a few previous occasions. In this instance, he was given supervision by his sergeant. He believed that the interpretation of the grower's statements was the responsibility of the attending officers. All officers had been given 1-hlong training session on the subject of modern slavery which he said was insufficient. He said that until guidance was improved, police had to rely on their professional instincts.

The OIC had, however, submitted an NRM (National Referral Mechanism) referral, on the basis of the information provided by the grower during his interview. This is the formal procedure by which possible modern slavery victims are identified and given support. The NCA, however, had returned this with the decision that the grower was not a slavery victim, commenting:

Modern slavery (Trafficking) has three component parts - action, means, and purpose, the purpose being for exploitation. When you say it doesn't matter if he consented, in terms of modern slavery (trafficking) it does. If he's consented then he hasn't been subjected to any of the means and he hasn't been subjected to exploitation.

\section{Case Study A: Discussion}

The attending police officer interviewer described the simplicity with which he had viewed his task - the interviewing of the suspect-which suggested a presumption that the grower should be treated as a suspect only. Whilst he undertook some questioning about the potential import of modern slavery legislation, this followed what might be called traditional 'binary' concepts of slavery to establish whether the grower was physically locked inside. When the grower answered in the negative, the officer appears to have dispensed with any notion of the grower being a victim. The transcript of his questioning showed that he had neglected the complexity and nuance which slavery may involve. This officer also demonstrated his deference to the grower; if he did not present himself as a victim, the police would not. His presumption that the grower should be treated as a suspect eclipsed the possibility that a victim may not realise that he had been victimised.

The police interviewer's view can be contrasted with the perspective of the OIC. He had concerns about modern slavery and made an NRM referral, yet seemed persuaded by the narrative that growers are offenders. Similarly to the interviewing officer, he mentioned that the grower had a previous conviction for involvement in cannabis cultivation, which appears to have persuaded him that the grower should be treated as a suspect. Neither officer described an investigation to unearth modern slavery. 
Yet the story provided by the grower is a compelling one suggesting modern slavery. The grower described a situation of debt bondage and having entered into a 'contract' before he left Vietnam. From the start, he was subjected to death threats and threats of violence. He had his passport taken from him by his traffickers. He was subjected to a precarious journey, when members of his travelling party were beaten and possibly killed. The details of the work that the victim would complete in the UK were withheld. Although he was not locked in the house, he felt unable to leave, and forced to work, due to the threats he had received.

To summarise, when the suspect was arrested, the presumption made by the officers was that he was an offender, not that he may have been a victim. As a result, no investigation was made that may have revealed otherwise.

\section{Case Study B: The Formal Police Response}

Case study B involved a cannabis farm discovered by the Metropolitan Police in June 2017 after an apparent attempted burglary at the premises. The Vietnamese man present was arrested for cannabis cultivation, illegal entry into the UK and abstracting electricity. In custody, he was interviewed in the presence of his legal advisor and an interpreter. The interview lasted $10 \mathrm{~min}$, comprising 11 questions, which were almost entirely about the cannabis set-up and the grower's involvement. He stated that he was there to water the plants. Otherwise, he answered 'no comment' to all questions, including the one posed regarding potential modern slavery. No modern slavery crime report was created, and no investigation regarding that matter was conducted. The grower pleaded guilty at court and was awaiting sentence at the time of this study's interview.

\section{Case Study B: The Grower's Interview}

The grower said he had wished to leave Vietnam to improve his economic situation. His mother borrowed money from neighbours, to pay agents to smuggle him to Russia. He had no passport, so the agents arranged paperwork for him. He had worked for several years in Russia as a factory machinist, accumulating savings. To travel to the UK, he had made a long and dangerous journey through Europe, involving smugglers by whom he was subjected to debt bondage:

I have to pay them. I were told by the agent that if I wanted to go to the UK, they would arrange it, but I would have to work for them to pay the debt.

After being smuggled into the UK in a lorry, he was taken to a house where cannabis was growing. To ensure that he completed the work required, he was locked inside the house and warned not to leave:

The Vietnamese man told me to work. He said work to finish in order to pay off the debt, and if you work hard you could leave this place, but remember never, never think about escape. I was told that if I tried to escape then I would be in trouble if they found me. They didn't tell me that they would kill me, they said they would harm me. 
He recalled that when the police initially arrived, he had been tired, in shock and disorientated and could not understand nor remember afterwards the questions they asked him. Importantly, he said his legal advisor simply advised him to plead guilty to cultivation. He was uncertain whether he should be considered a victim, due to the agreement he had made with the agents to be taken to the UK.

\section{Case Study B: The Police Interviews}

The OIC in this case said that he had volunteered to deal with this individual in custody but had been given very little direction. The training he had received on modern slavery had consisted of a 20-min input at training school. He remarked that he had considered potential trafficking offences and sought to establish whether the grower had been forced:

I obviously put various questions forward, trying to ascertain if he was forced or coerced into working in the address, which through an interpreter he said that he wasn't, asked him what his role was, and he said it was to water plants.

At the court hearing, the defence argued the grower had been trafficked. The CPS requested a further interview in prison, which had been completed by the police, and the grower disclosed that he had been trafficked and forced to work in the cannabis house. The officer stated he now believed the grower had been trafficked. He was receptive to the notion of cannabis growers also being victims. However, he suggested the onus is on a victim to volunteer such information.

Asked about better ways to deal with hidden modern slavery on cannabis farms, the officer said that more effective questioning may help to unearth it. However, when faced with a cannabis grower in custody, he said that the policing responsibility did not extend beyond asking him or her about any victimisation.

\section{Case Study B: Discussion}

As in case study A, the officer believed the police bore the responsibility for asking a grower whether they had been victimised, but he thought that the onus was on a grower to reveal that victimisation. The grower was not questioned thoroughly about modern slavery. Even had he been, he may still not have divulged much information, due to the legal advice he was given to answer 'no comment' during his police interview and later to plead guilty.

As before, the police managed this as a drugs case, with the presumption that the grower was an offender. As such, there was very limited questioning of the grower around modern slavery. No other investigation was conducted to seek to establish whether he was a victim so therefore the police failed to identify him as such.

\section{Case Study C: The Formal Police Response}

The subject was a 22-year-old Albanian male, with no known criminal record, arrested following the execution of a search warrant of premises with a sophisticated growing set-up for 70 cannabis plants and accompanying equipment. 
In custody, the suspect was interviewed for 9 min in the presence of his legal advisor and an interpreter. He answered 'no comment' throughout, including to the one question which may have assisted with an understanding of whether he was a victim of modern slavery, i.e. 'are you being forced into growing the cannabis?' This was potentially an opportunity missed, possibly due to the legal advice that the grower received.

\section{Case Study C: The Grower's Interview}

The grower stated he was an Albanian who had come to the UK for economic reasons. He had been threatened that time was running out to pay back his debt of 12,000 Euros, the cost of being smuggled to the UK. The agent said that he had a job for him growing cannabis and that if he worked in the house for 3 months, his debt would be settled.

\section{Case Study C: The Police Interviews}

The investigating officer said that when he was initially allocated this matter, his supervisor asked him to interview the grower and then release him under investigation. The officer was unhappy with this as he was concerned that the grower may have been a trafficking victim and viewed him with some sympathy. He had asked if he was held against his will but not whether he had faced threats or violence. To all questions, the grower answered 'no comment'.

The officer said the police were often frustrated by the stance adopted by growers:

We are there to try and help people in these situations. But if they don't want to talk to the police it's sort of hitting a brick wall really. In terms of him possibly being trafficked or forced into those conditions, there's always ways out of it, but if they're not ready to help you and talk to you, you can't really do much for them, can you?

The officer's frustrations appear centred on the grower, without apparently considering the influence of the legal advice he may have received, to answer questions "no comment'.

\section{Case C: Discussion}

This case indicates that the police response may often be 'framed' (Goffman 1974) around a perception that cannabis growers are essentially criminals. The grower's story pointed to various indicators of human trafficking and modern slavery. Yet, whilst the officer had concerns, he did not focus his investigation on them, deciding instead to ask the grower a question about whether he was a victim. As we have seen, placing the onus on a grower in such circumstances is not enough to identify victims of modern slavery.

\section{Discussion}

A reading of these cases might give the impression that police did consider modern slavery and did not entirely presume that the growers should be dealt with as suspects. 
After all, in each case, the suspect interviews included questioning regarding modern slavery. Also, in two of the cases, NRM referrals were made. Despite these considerations, however, the in-depth study suggests that a particular set of presumptions prevail in the police response.

At the heart of all these cases is an individual whose account raises substantial concerns that he may have been a modern slavery victim. The accounts are not identical. They reveal a range of abuses which could have been inflicted in the period between victims leaving their homeland and the discovery of their involvement in cannabis cultivation. But they share common themes. All three growers presented narratives of debt bondage backed up by threats as the reason that they performed criminal acts. A cynic might point to the words of Mandy Rice-Davies- "He would say that wouldn't he?"-but such a view might be myopic, given the growers' compelling stories, coupled with previous research suggesting an empirical link between cannabis growing and modern slavery (NPCC 2014). At the least, they do raise disturbing questions which merit consideration.

The police framing of growers as drugs criminals, with the accompanying perfunctory consideration of modern slavery fits nicely with traditional, 'binary' concepts of slavery. However, these cases have demonstrated the reality of how a narrative of smuggling can be transformed into one of trafficking, as Campana and Varese (2015) have suggested. Therefore, police agencies with aims to reduce harm and identify victims need to take a more holistic approach to identifying modern slavery, considering a modern understanding of what it may involve.

Of at least equal significance is the role of legal advisors and the advice they appear routinely and probably uncritically to give to individuals in such cases. The content of discussions between a suspect and their legal advisor are subject to 'legal privilege' which means they are protected from police scrutiny. It can be assumed, however, that lawyers may advise clients to admit guilt in order to receive a reduced sentence. Typically, when a cannabis grower is found or linked to a cannabis farm, they are charged with cultivation. Under Section 6 of the 1971 Act, cultivation is a triable 'either way' offence, punishable with a maximum of 14 years imprisonment and/or a fine when tried on indictment in a Crown Court. When tried summarily (in a Magistrates' Court), the maximum sentence is 6 month imprisonment and/or a fine. Faced with the choice between fighting charges in the Crown Court and pleading guilty in the lower court, many may prefer 'going quietly' rather than risk a lengthy sentence.

\section{Conclusions}

\section{Policy implications}

In his book, Orientalism, the public intellectual Edward Said (1978) described how values such as compassion and freedom are common to humanity. Despite this, these values are often presented as being 'western' in a dominant discourse that stresses 'otherness', which Said argued is in fact manufactured as part of a political reflex. Said illustrates how rather than cultures being clearly demarcated and insular, they continually feed each other in an enriching 'counterpoint'. 
Cannabis farm criminality might be seen as an exemplar of the police misframing their response, perhaps not seeing past the 'otherness' of those involved and failing to realise their suffering.

Despite the limitations of this study, it suggests that modern slavery may be present during the commercial cultivation of cannabis and in the 'continuum of unfreedom' and multiple abuses that growers may experience. These abuses are not necessarily consistent with traditional or binary explanations; victims may be held against their will, forced to work and be unable to leave, despite an unlocked door.

These findings have the following policy implications:

i) Investigative opportunities. Too often, the policing response to cannabis farms means that growers do not, and are not encouraged, to describe their experiences. However, this study has demonstrated the rich and illuminating detail that victim growers may provide. It is right that there is a certain onus on a grower to divulge, yet the police need to be aware that not all victims are conscious of the fact and significance of their own victimisation and that arrested cannabis growers may be advised to respond 'no comment' by legal advisors. They are almost certainly entirely ignorant of the law and procedure of the criminal justice system in England. The police are in a position to work better to encourage such accounts and investigate the presence of modern slavery without such an onus placed on a grower. An appropriately detailed disclosure to legal advisors in custody, including details such as the condition of the premises and grower, may encourage such an account, providing important information regarding victimisation.

ii) Abusers. This study has provided further empirical evidence of the modern slavery that can be associated with cannabis farms, yet currently little proactive policing goes into targeting such offenders. Re-framing of the policing response to cannabis farms, so that the possibility of modern slavery is more fully considered, would encourage a more careful, specialist approach, aimed at uncovering slavery in such cases. This could even include obtaining victim accounts which may reveal more about the workings and organisation of abusers.

iii) Training. It must be remembered that it is often uniformed front-line police officers who are sent to deal with these matters and continue the investigations thereafter. Yet, the complexities of the crime as described are perhaps those that deserve the attention of specialist investigators, to unearth and identify complex, hidden harm. Officers described doubts as to the effectiveness of their modern slavery training, and their responses demonstrated a lack of awareness of the realities of slavery. The review of the effects of the Modern Slavery Act 2015 carried out 1 year after it came into being (Haughey 2016) noted inconsistencies in police actions, gaps in the College of Policing's practice guidelines and a general deficit in police training, all of which continue to be under scrutiny by the IASC (IASC 2019).

Large questions remain about how the criminal justice system should ethically manage modern slavery victims who are also illegal immigrants involved in illegal activity. Yet research in the field is gathering momentum, and this small study may contribute to a growing body of knowledge about these victim/offenders.

\section{Afterword}

At the Accademia art gallery in Florence stand four unfinished sculptures by Michelangelo Buonarroti. Often ignored by gallery-goers focused on the nearby and exalted David, these 
'quattro prigioni', or 'four slaves', were left incomplete by Michelangelo. The slaves writhe amidst the hardship of their existence, but owing to their unfinished state, they remain obscured by the rock from which they appear unable to free themselves. An observer has an impression of the individual, yet not the entire human-perhaps emblematic of the current state of modern slavery in the UK with so much still to be learned.

Acknowledgements The first author wishes to thank the chief officers of Surrey Police for making this study possible. He us particularly grateful to then-DCC (now Chief Constable) Gavin Stephens, who enabled him to enrol in the Cambridge University M.St. course in applied criminology and police management, for which this study was conducted as a thesis. He is also grateful to the numerous colleagues who have helped him, most notably Simon Rose, Sam Taylor and his fellow Surrey students, as well as the cannabis growers and the police officers who agreed to be interviewed for this research.

Open Access This article is licensed under a Creative Commons Attribution 4.0 International License, which permits use, sharing, adaptation, distribution and reproduction in any medium or format, as long as you give appropriate credit to the original author(s) and the source, provide a link to the Creative Commons licence, and indicate if changes were made. The images or other third party material in this article are included in the article's Creative Commons licence, unless indicated otherwise in a credit line to the material. If material is not included in the article's Creative Commons licence and your intended use is not permitted by statutory regulation or exceeds the permitted use, you will need to obtain permission directly from the copyright holder. To view a copy of this licence, visit http://creativecommons.org/licenses/by/4.0/.

\section{References}

British Society of Criminology. January, 2015. Statement of Ethics. Retrieved, 25 ${ }^{\text {th }}$ July 2017 from: http://www.britsoccrim.org/new/docs/BSCEthics2015.pdf

Burland, P. (2015). The responses to trafficked adults in the United Kingdom: Rights, rhetoric and reality. $\mathrm{PhD}$ : University of the West of England.

Campana, P., \& Varese, F. (2015). Exploitation in human trafficking and smuggling. Eur J Crim Policy Res, 22(1), 89-105.

Campbell, D. T., \& Stanley, J. C. (1963). Experimental and quasi-experimental designs for research on teaching. In Gage, N.L. (Ed.), Handbook of research on teaching., Chicago, IL: Rand McNally. 171-246.

Craig, G. $8^{\text {th }}$ April 2015. 'Britain's modern slavery act: World-leading or a timid start?' E-INTERNATIONAL RELATIONS. Retrieved 10 ${ }^{\text {th }}$ April 20117 from: http://www.e-ir.info/2015/04/08/britains-modernslavery-act-world-leading-or-a-timid-start/

The Economist. $20^{\text {th }}$ September 2017. 'Modern slavery is disturbingly common'. Retrieved $20^{\text {th }}$ November 2017 from: https:/www.economist.com/blogs/graphicdetail/2017/09/daily-chart-12

Goffman, E. (1974). Frame analysis - An essay on the organization of experience. Boston: University Press of New England, Hanover and London.

Haughey, C. (2016) The modern slavery act review, July 2016. www.gov.uk/government/publications/modernslavery-act-2015-review-one-year-on

Hedge, J., \& Tarzi, A. (1996). A prison within a prison - 4 years on. In P. Green (Ed.), Drug couriers: A new perspective (pp. 127-135). London: Quartet Books.

Her Majesty's Inspectorate of Constabulary and Fire \& Rescue Services. (2017). Stolen freedom: The policing response to modern slavery and human trafficking. London: HMICFRS.

Hestia (2019). Underground lives: Police response to victims of modern slavery. https://www.hestia. org/undergroundlives

Home Office. (2016). Drug misuse: Findings from the 2015/2016 crime survey for England and Wales. London: Home Office.

Hyett, N., Kenny, A., and Dickson-Swift, V. $7^{\text {th }}$ May 2014. 'Methodology or method? a critical review of qualitative case study reports' International Journal of Qualitative Studies on Health and Well-Being. (9) Abingdon. Retrieved 10 th October 2017 from: https:/www.ncbi.nlm.nih.gov/pmc/articles/PMC4014658/ Independent Anti-Slavery Commissioner. (2019). Strategic plan 2019-21. London: IASC. 
The International Labour Office (ILO) and Walk Free Foundation. 19 ${ }^{\text {th }}$ September 2017. 'Forced labour and forced marriage'. Retrieved 10 $10^{\text {th }}$ November 2017 from: http://www.alliance87.org/global_estimates_of_ modern_slavery-forced_labour_and_forced_marriage.pdf

The Law Society. 29th October 2015. 'Defending victims of human trafficking'. Retrieved $16^{\text {th }}$ October 2017 from: http://www.lawsociety.org.uk/news/blog/defending-victims-of-human-trafficking/

Marshall, S., \& While, A. (1994). Interviewing respondents who have English as a second language: Challenges encountered and suggestions for other researchers. J Adv Nurs, 19, 566-571.

The National Crime Agency (NCA). 10 $0^{\text {th }}$ August 2017. 'Law enforcement steps up response to modern slavery'. Retrieved 12th October 2017 from: http://www.nationalcrimeagency.gov.uk/news/1171-lawenforcement-steps-up-response-to-modern-slavery

National Police Chief's Council (NPCC) (n.d.) 2014. UK national problem profile: Commercial cannabis cultivation. Retrieved 24th May 2017 from http://www.npcc.police.uk/Publication/FINAL\%20 PRESS\%20CULTIVATION\%20OF\%20CANNABIS\%202.pdf

Nicassio, P. M., Solomon, G. S., \& Guest, S. S. (1986). Emigration stress and language proficiency as correlates of depression in a sample of southeast Asian refugees. Int J Soc Psychiatry, 32, 22-28.

Potter, G. R. (2010). Weed, need and greed: A study of domestic cannabis cultivation. London, England: Free Association Press.

Sykes, G. (1971). The Society of captives: A study of a maximum security prison (1st ed.). Princeton, NJ: Princeton University Press.

Westermeyer, J. (1990). Working with an interpreter in psychiatric assessment and treatment. J Nerv Ment Dis, 178(12), 745-749.

Winstock, A., Barratt, M., Ferris, J., and Maier, L. 24 ${ }^{\text {th }}$ May 2017. 'Global Drug Survey 2017: Global overview and highlights'. Retrieved 11 th August 2017 from: https:/www.globaldrugsurvey.com/mwginternal/de5fs23hu73ds/progress?id=Db8N4uMPpmOoKtJy6fmPoF-1DITHC9VcbKp-eK_RByM,

Yin, R. K. (2009). Case study research: Design and methods (4th ed.). Thousand Oaks, CA: Sage.

Publisher's Note Springer Nature remains neutral with regard to jurisdictional claims in published maps and institutional affiliations.

Adam Ramiz M.St. (Cantab) is a Detective Inspector with the Surrey Police, assigned to the Criminal Justice Department.

Paul Rock D.Phil. (Oxon) FBA is Professor Emeritus of Sociology at the London School of Economics.

Heather Strang Ph.D. (Australian National University) is the Director of the Jerry Lee Centre of Experimental Criminology at the University of Cambridge.

\section{Affiliations}

\section{Adam Ramiz ${ }^{1} \cdot$ Paul Rock $^{2} \cdot$ Heather Strang ${ }^{3}$}

Heather Strang

HS404@cam.ac.uk

1 Surrey Police, Surrey, UK

2 London School of Economics, London, UK

3 University of Cambridge, Cambridge, UK 